\author{
Aleksandra Izbiańska \\ Uniwersytet Ekonomiczny we Wrocławiu \\ e-mail: aleksandra.izbianska@ue.wroc.pl
}

\title{
WPLYW PRZEOBRAŻEŃ POLITYCZNO- \\ -GOSPODARCZYCH W POLSCE I NA UKRAINIE NA \\ WYKORZYSTANIE INSTRUMENTÓW TARYFOWYCH \\ WE WZAJEMNEJ WYMIANIE HANDLOWEJ
}

\section{THE INFLUENCE OF POLITICAL AND ECONOMIC TRANSFORMATION IN POLAND AND UKRAINE ON THE USE OF TARIFF INSTRUMENTS IN TRADE EXCHANGE}

DOI: 10.15611/pn.2018.523.13

JEL Classification: F1, F19

Streszczenie: Przeobrażania polityczno-gospodarcze w Polsce i na Ukrainie miały duży wpływ na współczesne kształtowanie się wzajemnej wymiany handlowej między państwami. Po uzyskaniu niepodległości Ukraina musiała się zmagać z rosnącym kryzysem gospodarczym oraz społecznym. Narodowi ukraińskiemu trudno było się zjednoczyć ze względu na swoją różnorodność kulturową i światopoglądową. Autorka przeprowadziła próbę scharakteryzowania struktury polsko-ukraińskiej wymiany handlowej, na którą w dużej mierze wpływa sytuacja międzynarodowa państwa. Nie bez znaczenia są również różnorodne przepisy prawa celnego, które stanowią hamulec we wzajemnych kontaktach handlowych. Zawarcie przez Ukrainę umowy stowarzyszeniowej z Unią Europejską pozwoliło na unifikację przepisów celnych między państwami. Celem artykułu jest przybliżenie problemów związanych z wpływem przemian polityczno-gospodarczych na handel Polski z Ukrainą. Zagadnienie zostało przeanalizowane w kontekście wykorzystania instrumentów taryfowych.

Slowa kluczowe: handel, Ukraina, stosunki polsko-ukraińskie, prawo celne.

Summary: Political and economic transformations in Poland and Ukraine have had a major impact on the contemporary development of mutual trade between the two countries. Having regained independence, Ukraine had to deal with the growing economic and social crises. It was difficult for the Ukrainian nation to unite due to its cultural and ideological diversity. The author has attempted to characterize the structure of Polish-Ukrainian trade, which is largely influenced by the international situation of the state. Varying customs laws are also an important factor, as they hamper mutual commercial contacts. The conclusion of an association agreement with Ukraine by the European Union allowed for the unification of customs regulations between the states. The aim of the article is to present problems related to 
the impact of political and economic changes on trade between Poland and Ukraine. The issue was analyzed in the context of the use of tariff instruments.

Keywords: trade, Ukraine, Polish-Ukrainian relations, custom law.

\section{Wstęp}

Ze względu na odmienny przebieg procesu transformacji ustrojowej oraz odmienne uwarunkowania geopolityczne Polska i Ukraina są na różnych etapach rozwoju gospodarczego oraz politycznego. Polskie społeczeństwo w dobie przeobrażeń politycznych stanowiło monolit, czego nie można powiedzieć o obywatelach Ukrainy. Polacy mieli wspólną historię oraz kulturę, które stanowią fundament w każdym społeczeństwie obywatelskim. Po uzyskaniu przez Ukrainę niepodległości trudno było znaleźć wspólne punkty zaczepienia, które przyspieszyłyby reformy społeczne oraz gospodarcze. W odniesieniu do niedawnych wydarzeń związanych z kryzysem ukraińskim można zauważyć, że obywatele Ukrainy zaczęli mówić jednym głosem w sprawie przyszłości swojego kraju.

W dobie coraz większej globalizacji granice między państwami stopniowo się zacierają. W 2017 roku Polska znalazła się w gronie największych eksporterów na rynek ukraiński. Bezpośrednią tego przyczyną było wejście w życie na początku 2016 roku Umowy o pogłębionej i wszechstronnej strefie wolego handlu (DCFTA). Na zacieśnienie wzajemnych powiązań handlowych oddziałuje również coraz większa stabilizacja polityczna oraz gospodarcza Ukrainy. Nie da się jednak nie zauważyć, że kryzysy polityczne związane z aneksją Krymu czy wydarzeniami w Donbasie mają duży wpływ na stosunki handlowe Polski i Ukrainy. Jednak jak pokazuje dotychczasowa historia, Ukrainie udaje się, po chwilowym załamaniu, ustabilizować sytuację polityczno-gospodarczą. Można to prześledzić, analizując saldo wymiany handlowej w poszczególnych okresach. Po załamaniu ukraińskiego importu i eksportu w 2014 roku (rozpoczęcie działań zbrojnych w Donbasie) już w roku 2016 bilans wymiany handlowej wzrósł, a w 2017 powrócił do stanu sprzed kryzysu. Niestety na stabilność i liniowy rozwój ukraińskiej gospodarki ma wpływ polityka zagraniczna Rosji.

\section{Odmienne wizje reform politycznych i gospodarczych Polski i Ukrainy po 1989 r.}

Proces transformacji ustrojowej w europejskich krajach socjalistycznych rozpoczą się na przełomie lat 80 . i 90. XX wieku i w niektórych przypadkach trwa do dnia dzisiejszego. Przemiany polityczno-gospodarcze doprowadziły do przejścia z systemu centralnie planowanego do gospodarki wolnorynkowej. Ze względu na różne uwarunkowania polityczne, gospodarcze, społeczne, jak również historyczne Polski 
i Ukrainy proces dekomunizacji w tych krajach przebiegał w różny sposób i przyniósł odmienne skutki.

Polski proces transformacji ustrojowej wiązał się z kompleksowymi reformami politycznymi oraz gospodarczymi. Nowy rząd musiał zmagać się z hiperinflacją oraz dużym deficytem budżetowym. Ze względu na słabą kondycję polskiej gospodarki wprowadzono „Rządowy program stabilizacji gospodarczej”, zwany potocznie Planem Balcerowicza [Mikuła 2008]. Program, który był zbiorem ustaw, miał za zadanie ustabilizować i zliberalizować polską gospodarkę. W pierwszej kolejności zrestrukturyzowano system bankowy, który miał stać się gwarantem stabilnej pozycji polskiego złotego. Zreformowano system podatkowy, wprowadzając podatek dochodowy od osób fizycznych oraz podatek VAT [Onufer 2004]. Zliberalizowano handel przez odejście od wymiany barterowej na rzecz wolnodewizowej. Rozpoczęto również proces prywatyzacji przedsiębiorstw oraz usamodzielniono przedsiębiorstwa Skarbu Państwa. W 1991 roku został podpisany akt założycielski Giełdy Papierów Wartościowych w Warszawie [O spótce... 2018]. W ramach programu „Extended Fund Facility” Klub Paryski zgodził się na umorzenie 50\% długu Polski zaciągniętego $\mathrm{w}$ państwach zachodnich. Wszystkie działania związane z założeniami rządowego programu stabilizacji sprawiły, że sytuacja makroekonomiczna Polski w dłuższym okresie się poprawiła. Opanowano hiperinflację, która zagrażała stabilności gospodarczej kraju. W szybkim czasie udało się wzmocnić pozycję polskiego złotego, który stał się walutą wymienialną. Dzięki temu polska gospodarka stała się wolnorynkowa.

Reformy gospodarcze nie byłyby możliwe bez reform politycznych. W związku z tym duży nacisk położono na zmianę ówczesnej komunistycznej elity politycznej. Dzięki takiemu posunięciu reformy naprawcze przeprowadzane były w duchu demokratycznym. Co ciekawe, dużą rolę w przekształceniach odegrał Kościół katolicki, dzięki czemu cały proces można było uznać za pokojowy. Niezwykle ważnym momentem było wprowadzanie w 1997 roku nowej konstytucji, w której Polskę scharakteryzowano jako ,demokratyczne państwo prawne, urzeczywistniające zasady sprawiedliwości społecznej”.

17 października 1997 roku, czyli dzień wejścia w życie Konstytucji, można uznać za datę graniczną między okresem postkomunistycznym a demokratycznym w Polsce. Osiem lat pracy nad wolnorynkową gospodarką dało podstawę do analizy przebiegu procesu i skorygowania błędów, które popełniono przy tak trudnym procesie, jakim niewątpliwie jest zmiana systemu nakazowo-rozdzielczego na system wolnorynkowy. Profesor Grzegorz Kołodko wykazał, iż w „drugim” okresie samorządności państwowej należało odrzucić idee tworzenia programów restrukturyzacyjnych przez zagranicznych ekspertów, którzy nie znali polskich realiów, a także zmniejszyć restrykcje finansowe wobec przedsiębiorstw państwowych na poczet zwiększenia systemu nadzoru bankowego i ubezpieczeniowego przed decentralizacją i prywatyzacją banków. Ponadto wykazał, iż wykonano nadmierną dewaluację złotego i zbyt długo zamrażano kurs złotego względem dolara [Kołodko 
2017]. Francuski pisarz André Malraux powiedział, że „Kto boi się robić błędy, ten nigdy nie będzie tworzyć historii”. Chciałabym, aby ta myśl była podsumowaniem pierwszego okresu funkcjonowanie gospodarki wolnorynkowej. Mimo błędów, które popełniono, to zmiana ustroju gospodarczego w porównaniu z naszymi wschodnimi sąsiadami i tak wypada bardzo korzystnie.

O ,demokratycznej” Ukrainie możemy mówić od 1990 roku, gdy rząd Ukraińskiej Socjalistycznej Republiki Radzieckiej ogłosił „Deklarację suwerenności państwowej”, która wraz z aprobatą prezydenta Gorbaczowa miała zostać związana nową umową związkową między Rosją a Ukrainą. Ogłoszono ogólnokrajowe referendum, które miało zdecydować o suwerenności lub ponownym stowarzyszeniu się z chylącym się ku upadkowi Związkiem Radzieckim. 76\% społeczeństwa blisko 45-milionowego narodu opowiedziało się za powstaniem niezależnej i suwerennej Ukrainy [Winiarski 2010]. Był to moment przełomowy, ponieważ spotkanie przewodniczących komitetów centralnych partii komunistycznych Rosji, Białorusi i Ukrainy doprowadziło do rozpadu ZSRR i powstania Ukraińskiej Republiki Demokratycznej. 8 grudnia 1991 roku jest datą graniczną między starą a nową Ukrainą.

Naród ukraiński pokładał ogromne nadzieje w procesie demokratyzacji państwa. Społeczeństwo podzieliło się na dwie frakcje: entuzjastów zmian i pesymistów. Entuzjastami byli narodowi demokraci, którzy dążyli do całkowitej kapitalizacji i urynkowienia Ukrainy. Ich celem była jak najszybsza restrukturyzacja gospodarki, prywatyzacja oraz budowa własnego dobra kosztem zagranicznego kapitału. Drugą grupą byli natomiast ideowi komuniści, którzy uważali, że tylko „lud pracujący” może wypracować feudalny kapitał, który stanie się dorobkiem ich całego społeczeństwa. Podziały społeczne był zaskakująco duże w porównaniu z wynikami referendum, które pokazało, że Ukraina chce zakończenia „starych” porządków i rozliczenia poprzednich elit. Podział ten spowodował już na początku demokratyzacji Ukrainy pewien „falstart”. Niezdecydowanie co do wizji rozwoju państwa ugasiło entuzjazm uczestników stosunków międzynarodowych w niesieniu pomocy rozwojowej i wsparcia ekonomicznego. Wiele państw uważało Ukrainę za państwo niestabilne politycznie, w którym lokowanie swoich interesów jest bardzo ryzykowne. Szybko okazało się, że demokracja nie zapewnia szczęścia i dobrobytu, a daje jedynie szansę bezkrwawego rozwiązywania naturalnych w każdym społeczeństwie napięć i konfliktów. Demokraci uważali, że z dnia na dzień będzie lepiej. Natomiast osoby proradzieckie żyły w przekonaniu, że teraz może być już tylko gorzej. Tendencje te doprowadziły do powstania nowego kierunku rozwoju Ukrainy, tak zwanego „centrowego", który odsunął na boczny tor nie tylko ideowych komunistów, którzy nadal próbowali walczyć pod czerwonym sztandarem, ale też narodowych demokratów, od których przejęto część haseł i wzorców potrzebnych do budowania formalno-wizualnej strony państwowości ukraińskiej. W ten sposób powstał nowy nieoficjalny nurt polityczny: demokratyczno-oligarchiczny. 
Pierwszym skutkiem demokratyzacji ustroju Ukrainy była hiperinflacja. Do końca III kwartału 1992 roku osiągnęła ona poziom 10 000\% [Winiarski 2010]. Kraj popadał w ruinę, a ludzie zubożeli. Sondaż przeprowadzony jesienią 1992 roku wykazał, że 54\% osób, które głosowały za odłączeniem od ZSRR, przyznało, że to był błąd i z perspektywy czasu zagłosowaliby inaczej [Matuszak 2012]. Bieda powodowała, że zwykli ludzie coraz mniej interesowali się wielką polityką, chcieli pracować, by zapewnić byt swojej rodzinie. Narodowi demokraci, rozczarowani tempem zmian, zaczęli masowo emigrować na Zachód. Szacuje się, że w pierwszej połowie lat 90 . z Ukrainy wyjechało około 7 milionów ludzi, co stanowiło 17\% populacji całego społeczeństwa [Jaroszewicz 2014]. Ideowi komuniści, zamknięci mentalnie w ramach ustroju totalitarnego, zaczęli stawiać swoje pierwsze nieufne kroki w gospodarce wolnorynkowej. Walczyli o godne życie dla siebie i swoich rodzin. Tendencje „podziału” sprawiły, że po prawie dziesięciu latach większego czy mniejszego spadku inflacji w końcu zaczął się na Ukrainie wzrost gospodarczy. Bezrobocie się zmniejszyło, powodując pozytywne nastroje wśród obywateli. W zapomnienie odeszły też spekulacje opinii międzynarodowej, jak i samych Ukraińców na temat tego, czy większe jest poparcie dla ruchu „prozachodniego” czy „,prorosyjskiego", a świat przywykł do niepodległego państwa ukraińskiego. Jednak równolegle z tymi pozytywnymi tendencjami trwało kumulowanie własności przez obóz władzy. Kolejnym bowiem skutkiem słabości narodowo-demokratycznej opozycji było to, że niedawni komunistyczni aparatczycy czy „czerwoni dygnitarze” bardziej niż budowaniem efektywnie działających organów państwa zajęli się zawłaszczaniem majątku, który w czasach radzieckich miał status „,wspólnego dobra narodowego". Analityk polityczny W. Kaspruk przeanalizował prywatyzację większości spółek Skarbu Państwa Ukrainy. W swoim dziennikarskim śledztwie udowodnił, że prywatyzacja stała się głównie udziałem 300 rodzin związanych z Radą Najwyższą Ukrainy. Członkowie rodzin deputowanych i rządu ukraińskiego za bezcen przejmowali zasoby ukraińskiej gospodarki [Jaroszewicz 2014]. Kaspruk szacuje, że $80 \%$ bogactwa narodowego znalazło się w rękach $4 \%$ społeczeństwa. Władza stała się więc źródłem wzbogacenia, bogactwo źródłem władzy, a życie polityczne zaczęło tracić charakter ideologiczny. Partyjnym oligarchom coraz bardziej zależało na utrzymaniu się przy władzy. Różnymi sposobami próbowali nakłonić wyborów do głosowania na ich osobę czy partię w wyborach. Większość „wybrańców narodu” brała udział w wyborach nie po to, aby realizować polityczną wizję i rozwiązywać problemy trapiące społeczeństwo, a po to, żeby jak najkorzystniej spieniężyć otrzymany od wyborcy „kredyt zaufania”. W ten sposób powstała trzecia po prezydencie i Radzie Najwyższej Ukrainy władza - oligarchowie. Należy jednak się zastanowić, w jakiej hierarchii ważności władzy należy ująć oligarchów. Znając historię, bez wahania można powiedzieć, że na Ukrainie władze sprawowała jedna „frakcja”oligarchia. 


\section{Struktura polsko-ukraińskiej wymiany handlowej}

Wymiana handlowa pomiędzy Polską a Ukrainą uwarunkowana jest politycznie, gospodarczo oraz prawnie. Wygląd i struktura wymiany w dużym stopniu zależy od sytuacji makroekonomicznej obu państw. Na wzajemną współpracę mają również wpływ naciski na Ukrainę ze strony Federacji Rosyjskiej. Niestabilna sytuacja gospodarcza i polityczna Ukrainy oraz różnice kulturowe obu państw są głównym hamulcem we wzajemnej współpracy [Lewandowska i in. 2014].

Ze względu na członkostwo Polski w Unii Europejskiej handel pomiędzy dwoma państwami regulowany jest w dużej mierze umowami Ukrainy z UE. Podstawą prawną kształtującą wzajemne relacje gospodarcze Polski i Ukrainy jest Porozumienie o Partnerstwie i Współpracy podpisane w 1994 roku. W 2004 roku podpisano protokół, który włączył do porozumienia również Polskę. W 2014 roku Ukraina podpisała Układ o stowarzyszeniu między Unią Europejską i jej państwami członkowskimi, z jednej strony, a Ukrainą, z drugiej strony, której nienaruszalnym postanowieniem jest Umowa o pogłębionej i wszechstronnej strefie wolego handlu (DCFTA) [Informacje o kraju... 2018].

Punktem przełomowym we wzajemnych relacjach Polski z Ukrainą było stworzenie przez Polskę i Szwecję koncepcji tzw. partnerstwa wschodniego. Jej ideą było pogłębianie relacji gospodarczych Unii Europejskiej z krajami postsocjalistycznymi, bez możliwości członkostwa tych państw w Unii Europejskiej. Ukraina przystąpiła do partnerstwa w Pradze w 2009 roku. Jednak realne zmiany, które pozwoliły zliberalizować handel, nastąpiły dużo później [Płonka 2015]. W ciągu lat relacje gospodarcze pomiędzy Polską a Ukrainą pogłębiają się. Po okresie spowolnienia gospodarczego, jakie miało miejsce na przełomie 2010 i 2011 roku, udział wymiany handlowej pomiędzy Polską a Ukrainą wzrósł. Warto w tym miejscu zaznaczyć, że wzajemne stosunki gospodarcze między państwami są asymetryczne. Eksport krajów UE na Ukrainę jest prawie dziesięć razy większy niż import [Unia Europejska zalata... 2017].

Na podstawie danych z GUS-u, przedstawionych w formie wykresów, można zauważyć, że w 2014 i 2015 roku nastąpił spadek zarówno polskiego eksportu, jak i importu. Kryzys ukraiński był bezpośrednią przyczyną osłabienia gospodarczego i politycznego Ukrainy. Jednak już od 2016 roku eksport i import dynamicznie wzrasta.

Zarówno w roku 2016, jak i w roku 2017 wymiana handlowa pomiędzy Polską a Ukrainą wzrosła średnio o $20 \%$. Według danych pochodzących z GUS polski eksport wzrósł o 25\%, a import o 19\% w stosunku do 2016 roku [Dziedzinowa baza... 2018].

Według komunikatu GUS, w pierwszym półroczu 2017 roku, wielkość polskiego eksportu ukształtowała się na poziomie sprzed kryzysu ukraińskiego. Według ekspertów „Gazety Prawnej” w 2017 roku udało się nadrobić straty, jakie polska gospodarka odnotowała w latach 2014-2015. W efekcie kryzysu ukraińskie PKB 
Rok: 2010, 2011, 2012, 2013, 2014, 2015, 2016, 2017

Kraj: UA - Ukraina

Waluta: tys. USD

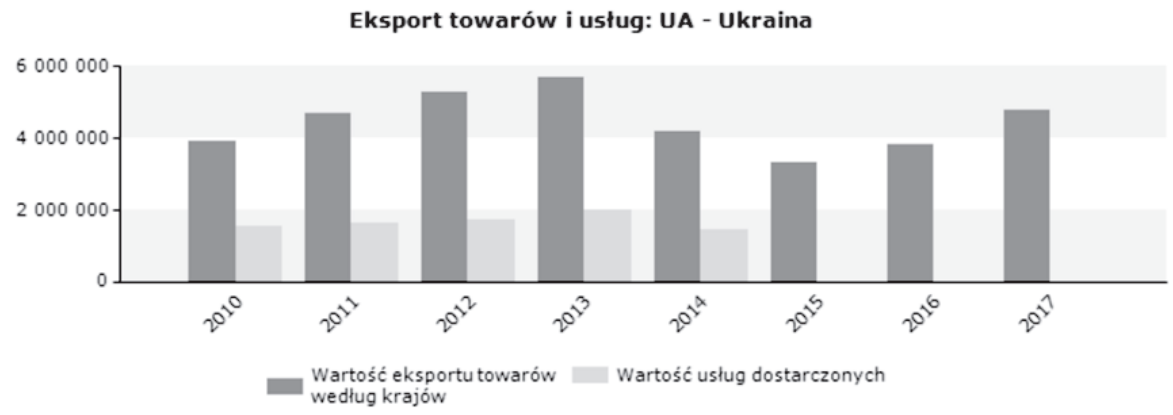

Rys. 1. Polski eksport na rynek ukraiński na przestrzeni lat 2010-2017

Źródło: http://swaid.stat.gov.pl/SitePagesDBW/HandelZagraniczny.aspx [dostęp: 06.03.2018].

Rok: 2010, 2011, 2012, 2013, 2014, 2015, 2016, 2017

Kraj: UA - Ukraina

Waluta: tys. USD

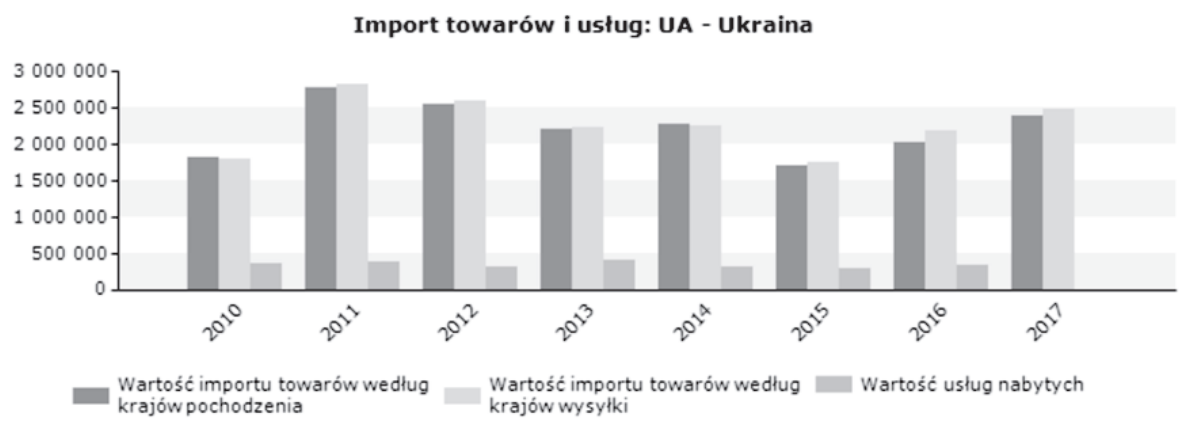

Rys. 2. Polski import z Ukrainy w latach 2010-2017

Źródło: http://swaid.stat.gov.pl/SitePagesDBW/HandelZagraniczny.aspx [dostęp 06.03.2018]

spadło w 2014 roku o 6,6\%, a w 2015 o 9,8\%. Zachwianie to, jak się później okazało, było tylko chwilowe [Eksport z Polski... 2017]. Porównując styczeń 2016 r. ze styczniem 2017 r., można zauważyć duży wzrost obrotów polskich i ukraińskich towarów. Według danych z Portalu Promocji Handlu w styczniu 2017 roku Ukraina odnotowała 40-procentowy wzrost obrotu towarów z Polską w stosunku do stycznia 2016 roku [Musiałowicz 2017].

Na podstawie danych z 2016 roku można wywnioskować, że Polska importuje przede wszystkim wyroby metalurgiczne (stanowiące 26,3\% udziału), artykuły rol- 
Tabela 1. Bilans handlowy Polski z Ukrainą w 2017 roku

\begin{tabular}{|c|c|c|c|c|c|}
\hline \multirow{3}{*}{ Wyszczególnienie } & \multicolumn{5}{|c|}{ I - XII 2017} \\
\hline & \multirow[b]{2}{*}{ Import w USD } & \multirow[b]{2}{*}{ Eksport w USD } & \multirow[b]{2}{*}{ Saldo w USD } & \multicolumn{2}{|c|}{ I - XII $2016=100$} \\
\hline & & & & Import & Eksport \\
\hline Luksemburg & 416526715 & 358314333 & -58212382 & 146,9 & 140,9 \\
\hline kotwa & 432181470 & 1478088133 & 1045906663 & 119,7 & 100,3 \\
\hline Macedonia & 142057386 & 139351453 & -2705933 & 180,2 & 175,9 \\
\hline Malta & 44095559 & 49757043 & 5661484 & 154,2 & 107,1 \\
\hline Mołdawia & 123304163 & 195247470 & 71943307 & 185,9 & 121,0 \\
\hline Niemcy & 52601697025 & 62541767681 & 9940070656 & 112,4 & 111,4 \\
\hline Norwegia & 2450251587 & 2648833700 & 198582113 & 116,7 & 107,4 \\
\hline Portugalia & 761636183 & 982832088 & 221195905 & 116,0 & 118,6 \\
\hline QQ w ramach handlu $z$ UE & 9782 & 58244774 & 58234992 & $x$ & 159,7 \\
\hline QU w ramach handlu $z$ UE & 3044561 & 17917202 & 14872641 & 85,6 & 84,0 \\
\hline QX w ramach handlu $z$ UE & 7116762 & 174818 & -6941944 & 100,6 & 45,6 \\
\hline Rosja & 14776735506 & 6946616544 & -7830118962 & 127,7 & 120,1 \\
\hline Rumunia & 2047844590 & 4243143716 & 2195299126 & 113,9 & 116,1 \\
\hline San Marino & 7186149 & 28513363 & 21327214 & 111,5 & 84,2 \\
\hline Serbia & 364849290 & 905588694 & 540739404 & 129,5 & 117,0 \\
\hline Słowacja & 4056354473 & 5746761067 & 1690406594 & 101,1 & 113,7 \\
\hline Slowenia & 839449274 & 898311006 & 58861732 & 119,9 & 118,4 \\
\hline Szwajcaria & 1651839463 & 2160889254 & 509049791 & 109,3 & 113,0 \\
\hline Szwecja & 4184740344 & 6320838085 & 2136097741 & 119,4 & 106,3 \\
\hline Ukraina & 2397591452 & 4784483781 & 2386892329 & 118,5 & 124,8 \\
\hline
\end{tabular}

Źródło: http://swaid.stat.gov.pl/SitePagesDBW/HandelZagraniczny.aspx [dostęp 06.03.2018].

no-spożywcze $(24,2 \%)$, produkty mineralne $(19,1 \%)$, wyroby papiernicze $(11,2 \%)$ oraz artykuły przemysłu elektromaszynowego (6,3\%). Jeśli chodzi o eksport, to podstawę stanowią produkty mineralne $(15,9 \%$ udziału), materiały sztuczne i polimery $(9,6 \%)$, maszyny elektryczne $(8,8 \%)$, reaktory jądrowe i maszyny $(8,7 \%)$ oraz środki transportu lądowego (3,6\%, wyłączając kolej).

Poruszając zagadnienie struktury wymiany handlowej pomiędzy Polską a Ukrainą, należy również wspomnieć o skutkach wejścia w życie porozumienia o wolnym handlu pomiędzy Unią Europejską a Ukrainą - DCFTA. Według brukselskiego generalnego dyrektoriatu ds. handlu Ukraina nie do końca skorzystała na umowie z Unią Europejską. Z danych statystycznych wynika, że kraje UE zwiększyły swój eksport o 2,575 mld euro, podczas gdy Ukraina tylko o $243 \mathrm{mln}$ euro. Dla wielu ukraińskich przedsiębiorców proces dostosowywania się do unijnych przepisów okazał się zbyt kosztowny i skomplikowany. Ukraińskie saldo obrotów z UE w 2016 roku wyniosło -3,4 mld euro [Musiałowicz 2017].

\section{Cla i procedury celne Polski w kontekście wymiany handlowej z Ukrainą}

Polskie prawodawstwo wskazuje dwa najważniejsze akty prawne związane z procedurami celnymi Rzeczypospolitej Polskiej. Pierwszy z nich to Ustawa z dnia 
19 marca 2004 roku - Prawo celne (Dz.U. z 2003 roku, nr 68 poz. 622 z późn. zm.), która porządkuje zasady i tryb przywozu towarów na danym obszarze celnym oraz reguluje wywóz towarów z obszaru celnego oraz związane z tym prawa i obowiązki osób zajmujących się przewozem towarów. Ponadto wskazuje uprawnienia i obowiązki organów celnych, wskazując jednocześnie konkretny zakres prac związanych z przestrzeganiem prawa celnego w Polsce. Drugim aktem normatywnym powszechnie obowiązującym jest Rozporządzenie Rady Unii Europejskiej z dnia 9 października 2013 roku ustanawiające Unijny Kodeks Celny (Dz. Urz. UE L 952/2013 z późn. zm.). Cechą charakterystyczną tego nowego dokumentu wspólnotowego w porównaniu z poprzedzającymi go dokumentami jest ujednolicenie obsługi obrotu towarowego z zagranicy w całej Unii Europejskiej przez zharmonizowane zasady wymiany informacji celnej i zakres tych danych. Do narzędzi wykorzystywanych w tej dziedzinie możemy zaliczyć ,Zintegrowany System Celno-Podatkowy" ICDTS, składający się z systemów ZEFIR, CELINA i NCTS [Bronowski 2016], które pomagają harmonizować procedury celne na całym obszarze wspólnotowym. W kontekście ukraińskim katalizatorem i czynnikiem ściśle normującym była umowa o pogłębionej i całościowej strefie wolnego handlu między Unią Europejską a Ukrainą (DCFTA), która zniosła wiele barier we wzajemnej wymianie handlowej. Ratyfikowana przez Radę Najwyższą Ukrainy 16 września 2014 r. umowa weszła w życie 1 stycznia 2016 r. i była najważniejszą i największą częścią podpisanej w czerwcu 2014 roku umowy stowarzyszeniowej między Ukrainą a UE. Umowa przewiduje nie tylko powołanie strefy wolnego handlu, ale także przyjęcie przez Ukrainę ok. $60 \%$ prawa Unii Europejskiej, w tym regulacji w zakresie energii, przepisów technicznych, sanitarnych, fitosanitarnych, celnych i dotyczących ochrony własności intelektualnej. Ma ponadto zabezpieczyć przepływ kapitału oraz stworzyć równe warunki konkurencji. Od tego momentu można mówić o „swobodnej” wymianie handlowej między Polską a Ukrainą. Kolejnym czynnikiem pozytywnie wpływającym na wymianę handlową między państwami wspólnotowymi są tak zwane taryfy celne Unii Europejskiej, które Polska musiała ratyfikować wraz z przyjęciem Zharmonizowanego Systemu Oznaczania i Kodowania Towarów. Polegają one na określeniu stawki konwencyjnej, to znaczy takiej, która wynika z porozumień wielostronnych, takich jak GATT (Układ Ogólny w sprawie Taryf Celnych i Handlu) oraz WTO (Światowa Organizacja Handlu), które są stosowane wobec wszystkich krajów objętych klauzulą największego uprzywilejowania. Przyjęcie przez Polskę Wspólnej Taryfy Celnej Unii Europejskiej, a co za tym idzie wspólnotowego poziomu stawek celnych w imporcie z krajami objętymi klauzulą największego uprzywilejowania spowodowało obniżenie średniej stawki ważonej dla towarów przemysłowych z poziomu $6,2 \%$ do poziomu $2,6 \%$. Funkcjonuje również Zintegrowana Taryfa Celna Wspólnoty Europejskiej w skrócie TARIK. Jest to corocznie aktualizowany w IV kwartale dokument uchwalany przez Komisję Europejską i publikowany w Dzienniku Urzędowym Wspólnoty Europejskiej. TARIK zajmuje się automatyczną transmisją ustawodawstwa Wspólnoty Europejskiej do 
krajowych administracji państw członkowskich UE. Państwa wspólnotowe otrzymują przepisy Unii Europejskiej w specjalnie sformatowanych systemach elektronicznych, które wspomagać mają krajowe systemy odpraw celnych. Baza danych będąca w zasobach tego systemu jest ogólnie dostępna i codziennie aktualizowana. Kodowanie taryf celnych odbywa się za pomocą 10 znaków, które określają stawki celne wyrażone w procentach lub kwocie za określoną jednostkę dla danego państwa lub grupy państw, z którego towar przybywa. Ponadto zawiera podstawę prawną z komentarzem i odnośnikiem do przypisu, okresem ważności stawki celnej, dane do nadzoru importu i eksportu oraz limity ilościowe danego produktu. Z kodu TARIC można wyczytać również wskaźniki antydumpingowy, zawieszenia cła, preferencje celne, zwroty eksportowe, cła wyrównawcze, zakazy importu i eksportu. Nie zawiera natomiast informacji o narodowych podatkach, takich jak stawki VAT czy akcyzy.

\section{Cla i procedury celne Ukrainy a wymiana handlowa z Polską}

Najważniejszym aktem regulującym cła i procedury celne jest ustawa $\mathrm{z}$ dnia 13 marca 2012 r. „Kodeks celny Ukrainy”. Kolejnym niezwykle istotnym dokumentem jest ustawa z dnia 19 września 2013 r. „O taryfie celnej Ukrainy”. Od 16 maja 2008 r. Ukraina jest członkiem Światowej Organizacji Handlu, co w dużym stopniu ujednoliciło przepisy celne. W związku z kryzysem ukraińskim, czego bezpośrednią przyczyną była aneksja Krymu, utworzona została wolna strefa ekonomiczna, która funkcjonuje na Półwyspie Krymskim. Jej działanie reguluje ustawa „O utworzeniu wolnej strefy ekonomicznej Krym, cechy działalności gospodarczej na tymczasowo okupowanym terytorium Ukrainy”. Zgodnie z jej założeniami każda dostawa na i z terytorium Krymu jest traktowana jako eksport i import [Szymborska 2015]. Niezwykle ważnym wydarzeniem było podpisanie 16 września 2014 roku Umowy stowarzyszeniowej pomiędzy Ukrainą a Unią Europejską. Głównym założeniem porozumienia jest liberalizacja handlu oraz harmonizacja przepisów ukraińskich z unijnymi. Proces ten rozłożony jest na dziesięć lat [Ukraina przewodnik po rynku 2016].

Przy przywozie towarów na teren Ukrainy, co wiąże się bezpośrednio z odprawą celną, zasadniczą kwestią są kody towarowe, które określane są na podstawie Ukraińskiej Klasyfikacji Towarów Zagranicznej Działalności Gospodarczej (UKTZED). Na podstawie kodów naliczane są stawki celne, ulgi oraz ustalana jest właściwa procedura celna. Barierą we wzajemnych kontaktach handlowych jest fakt, że ukraińska klasyfikacja towarowa różni się od tej stosowanej w Polsce czy w innych krajach UE. Problematyczną kwestią jest również to, że ostateczną decyzję odnośnie do klasyfikacji towarowej podejmują organy celne Ukrainy.

W celu ochrony interesów gospodarczych Ukrainy wprowadzone zostały szczególne rodzaje stawek celnych importowych, które określane są przez ustawę 
„O taryfie celnej Ukrainy”. Zgodnie z Kodeksem celnym Ukrainy można wyróżnić następujące rodzaje stawek celnych na towary importowane:

- stawki preferencyjne - taki rodzaj stawek jest stosowany w stosunku do importu z krajów, z którymi Ukraina ma podpisane porozumienia o unii celnej lub o preferencyjnym trybie celnym;

- stawki ulgowe - taki rodzaj stawek jest stosowany w stosunku do importu z krajów, z którymi Ukraina ma na zasadzie wzajemności klauzulę najwyższego uprzywilejowania;

- $\quad$ stawki pełne - taki rodzaj stawek jest stosowany w stosunku do importu z pozostałych krajów oraz w przypadku braku certyfikatu o pochodzeniu towaru [Wydział Promocji Handlu... 2015].

Na podstawie „Umowy o partnerstwie i współpracy pomiędzy Wspólnotami Europejskimi i ich krajami członkowskimi a Ukrainą" państwa UE i Ukraina mogą korzystać z klauzuli najwyższego uprzywilejowania. W związku z powyższym na import towarów pochodzących z Polski do 2015 roku obowiązywała ulgowa stawka celna. Na mocy porozumienia DCFTA kraje UE oraz Ukraina wprowadziły zerowe lub obniżone stawki celne na większość towarów importowych $(99,1 \%$ po stronie Ukrainy i $98,1 \%$ po stronie UE) [Europa chce... 2017]. Warunkiem koniecznym do zastosowania preferencyjnej stawki celnej jest przedstawienie przez importera świadectwa przewozowego EUR 1, który potwierdza pochodzenie towarów. Dokument ten jest wystawiany bezpłatnie przez właściwy urząd celny eksportera [Co to jest... 2018].

Cła eksportowe na Ukrainie ustalane są na podstawie odpowiednich ustaw i rozporządzeń. Są stosowane na dane grupy towarów bez względu na to, gdzie są eksportowane (wyjątek stanowi eksport do państw będących członkami Wspólnoty Niepodległych Państw, Czarnogóry oraz Macedonii). W chwili obecnej cłami eksportowymi objęte są następujące towary: określona grupa zwierząt hodowanych, niektóre rodzaje nasion roślin oleistych, niektóre rodzaje metali nieszlachetnych oraz pewien rodzaj gazu ziemnego [Ukraina przewodnik po rynku 2016].

Charakterystyczne dla ukraińskiego prawa celnego jest istnienie cła sezonowego zarówno w eksporcie, jak i w imporcie. Jak sama nazwa wskazuje, cła sezonowe mogą zostać wprowadzone maksymalnie na cztery miesiące. Aktualnie Ukraina nie ma towarów objętych tą stawką. Do tej pory rząd ukraiński wprowadził cła sezonowe dwa razy - w 1998 r. i 1999 r., przede wszystkim na towary rolne [Co to jest... 2018]. Drugim charakterystycznym rozwiązaniem jest pobieranie przez ukraińskie organy jednolitej opłaty celnej. Opłata pobierana jest w przypadku przeprowadzania przez ukraińskie władze kontroli (celnej, fitosanitarnej, ekologicznej, weterynaryjnej itp.) na towary wwożone na teren państwa. Eksporter ponosi jednolitą opłatę celną także w przypadku korzystania z ukraińskich dróg przy przywozie towarów, szczególnie tych ponadgabarytowych. Stawki opłaty wyrażone są w euro i pobierane są w punktach przejść granicznych. 


\section{Zakończenie}

Podsumowując analizę polsko-ukraińskiej wymiany handlowej, należy stwierdzić, że mimo różnic wynikających z odmiennego usytuowania w politycznej przestrzeni Europy, z roku na rok wymiana ta się rozwija. Niewątpliwie znaczny wpływ na ten fakt ma dostosowywanie prawa, w tym prawa celnego, przez Ukrainę do standardów Unii Europejskiej. Wzrost wymiany handlowej towarów i usług jest korzystny dla obu krajów i z pewnością ma wpływ na rozwój gospodarczy Ukrainy i jej możliwość znalezienia się we wspólnocie europejskiej. Podpisanie „Umowy o partnerstwie i współpracy pomiędzy Wspólnotami Europejskimi i ich krajami członkowskimi a Ukrainą" w znacznym stopniu ułatwiło i usprawniło wymianę handlową między sygnatariuszami. Uzyskanie przez Ukrainę klauzuli najwyższego uprzywilejowania pozwoliło na objęcie zerowymi stawkami celnymi dużej części importu i eksportu. Istnieją jednak obszary, które w jeszcze większym stopniu usprawniłyby handel Polski z Ukrainą. Do chwili obecnej Ukraina stosuje kody towarowe, które określane są na podstawie Ukraińskiej Klasyfikacji Towarów Zagranicznej Działalności Gospodarczej (UKTZED), odmienne od stosowanych przez Unię Europejską. Fakt ten na pewno nie wpływa na ułatwienia w wymianie handlowej.

Jednocześnie trzeba zauważyć, że zawirowania polityczne, aneksja Krymu oraz sytuacja w Donbasie mają bardzo duży wpływ na stosunki handlowe Ukrainy zarówno z Polską, jak i z innymi krajami europejskimi. Także agresywna polityka Rosji i próby wciągnięcia Ukrainy w swoją strefę wpływów kładzie się cieniem na polsko-ukraińskiej współpracy handlowej.

\section{Literatura}

Bronowski R., Michalak M., 2016, Harmonizacja wymiany informacji elektronicznej w Unii Celnej UE, ICM Uniwersytetu Warszawskiego.

Co to jest dokument EUR 1?, https://kontener.pl/co-to-jest-dokument-eur-1/) [dostęp 06.03.2018 r.].

Dziedzinowa Baza Wiedzy Handel Zagraniczny, http://swaid.stat.gov.pl/SitePagesDBW/ HandelZagraniczny.aspx [dostęp 06.03.2018 r.].

Eksport z Polski na Ukrainę w 2017 roku będzie rekordowy, http://www.wnp.pl/rynki-zagraniczne/eksport-z-polski-na-ukraine-w-2017-roku-bedzie rekordowy, 314032_1_0_0.html [dostęp 28.12.2017 r.].

Europa chce produktów z Ukrainy. Stawia ważny warunek, https://tvn24bis.pl/ze-swiata,75/obnizeniecel-na-produkty-z-ukrainy,737054.html [dostęp 05.05.2017 r.].

Informacje o kraju, http://www.informatorekonomiczny.msz.gov.p1/p1/europa/ukraina [dostęp 06.04.2018].

Jaroszewicz M., Perspektywy migracji Ukrainców do EU, Ośrodek Studiów Wschodnich, www.osw. waw.pl/pl/publikacje/komentarze-osw/2014-02-25/perspektywy-migracji-ukraincow-do-ue [dostęp 25.02.2014 r.].

Kissinger H., 2014, To settle the Ukraine crisis, start at the end, The Washington Post.

Kołodko G., 2017, Sukces na dwie trzecie. Polska transformacja ustrojowa i lekcje na przyszłość, Studia Ekonomiczne. 
Lasiński-Sulecki K., Morawski W. i in., 2008, Wspólnotowy kodeks celny i przepisy wykonawcze, Wolters Kluwer.

Lewandowska A., Inglot-Brzęk E., Harasym R., 2014, Determinants of Polish Exports to the Ukrainian Marke, Barometr Regionalny Wyższej Szkoły Zarządzania i Administracji w Zamościu.

Matuszak S., 2012, Demokracja oligarchiczna - wplyw grup biznesowych na ukraińska politykę, Ośrodek Studiów Wschodnich.

Mearsheimer J., 2014, Why the Ukraine Crisis Is the West's Fault: The Liberal Delu-sions That Provoked Putin, Foreign Affairs.

Mikuła P., 2008, Bilans przemian społecznych i gospodarczych w Polsce w latach 1989-2006, ZNZE Wyższej Szkoły Informatyki i Zarządzania w Rzeszowie.

Musiałowicz B., Wymiana handlowa z Ukrainq w 2016 r., https://ukraine.trade.gov.pl/pl/ukraina/analizy-rynkowe/238234,wymiana-handlowa-z-ukraina-w-2016-r-.html [dostęp 7.04.2017 r.].

Onufer M., 2004, Transformacja systemowa w Polsce: stracona szansa czy otwarcie drzwi do jednoczacej się Europy?, Wydawnictwo Uniwersytetu Wrocławskiego.

O spółce, https://www.gpw.pl/o-spolce\#historia [dostęp 06.03.2018 r.].

Płonka B., 2015, Umowa UE-Ukraina o utworzeniu pogłębionej i kompleksowej strefy wolnego handlu (DCFTA) jako przykład nowej generacji porozumień preferencyjnych, Zeszyty Naukowe Wyższej Szkoły Zarządzania i Bankowości w Krakowie.

Rymarczyk J., 2017, Handel zagraniczny. Organizacja i technika, Polskie Wydawnictwo Ekonomiczne.

Szymborska N., Wprowadzenie cła na wywóz towarów z Ukrainy do Krymu, https://ukraine.trade.gov. $\mathrm{pl} / \mathrm{pl} / \mathrm{abc}$-biznesu/podatki-cla/132771,wprowadzenie-cla-na-wwoz-towarow-z-ukrainy-do-krymu. html [dostęp 11.10.2015 r.].

Ukraina przewodnik po rynku, https://ukraine.trade.gov.pl/pl/ukraina/gospodarka/235812, ukraina-przewodnik-po-rynku-2016.html [dostęp 22.03.2017 r.].

Unia Europejska zalała towarami Ukrainę, http://www.rp.pl/artykul/1311024-Unia-Europejska-zalala-towarami-Ukraine [dostęp 27.02.2017 r.].

Winiarski M., 2010, Polska i Ukraina na drodze do wspólnej Europy, Wydawnictwo Uniwersytetu Wrocławskiego.

Wydział Promocji Handlu i Inwestycji Ambasady Rzeczypospolitej Polskiej w Kijowie, 2015, Prawo celne - część II. Cla i inne opłaty zwiazane z odprawa celna. 